See discussions, stats, and author profiles for this publication at: https://www.researchgate.net/publication/316536422

\title{
Persistence of Ascaris spp. Ova in Tropical Soil Cultivated with Eucalyptus and Fertilized with Municipal Biosolids
}

Article in Journal of Environmental Quality · May 2017

DOI: $10.2134 /$ jeq2016.08.0305

CITATIONS

2

12 authors, including:

Marianne Fidalgo de Faria

São Paulo State University

12 PUBLICATIONS 6 CITATIONS

SEE PROFILE

Maria Ines Sato

Companhia Ambiental do Estado de São Paulo

118 PUBLICATIONS 1,154 CITATIONS

SEE PROFILE

Some of the authors of this publication are also working on these related projects:

Project Quantifying and comparing soil carbon stocks: Underestimation with the core sampling method View project

Thinning treatments reduce deep soil carbon and nitrogen stocks in a coastal Pacific Northwest forest View project
READS

90

Iraê Amaral Guerrini

São Paulo State University

113 PUBLICATIONS 870 CITATIONS

SEE PROFILE

Elayse M Hachich

Companhia Ambiental do Estado de São Paulo

20 PUBliCATIONS 353 CITATIONS

SEE PROFILE 


\title{
Persistence of Ascaris spp. Ova in Tropical Soil Cultivated with Eucalyptus and Fertilized with Municipal Biosolids
}

\author{
Marianne F. de Faria, ${ }^{*}$ Iraê A. Guerrini, Fernando C. Oliveira, Maria Inês Z. Sato, Elayse M. Hachich, \\ José Raimundo S. Passos, Lívia M. L. Goulart, Thiago T. de S. Silva, José L. Gava, Joel C. Furches, \\ Jason James, and Robert B. Harrison
}

\begin{abstract}
In many countries, the main reason for severely restricting or outright banning the land application of class B biosolids is the lack of risk assessment for adverse human health impacts. Among pathogens that are not often studied are helminth ova, including that of the Ascaris spp. Almost all of the knowledge about the persistence of Ascaris spp. ova in soils fertilized with biosolids is based on studies developed in North America, Europe, and Asia. These studies have almost always been conducted under temperate climate conditions, which may cause erroneous interpretations when the conclusions are extrapolated to tropical regions such as those found in Brazil. This team evaluated the persistence of viable Ascaris spp. ova in a sandy Quartzipsamment tropical soil, previously planted with Eucalyptus urophylla $\times$ Eucalyptus grandis hybrid (Eucalyptus urograndis) and fertilized with biosolids, over a 52-wk period. During the reporting period, the average temperature of soil and biosolids fluctuated between 15 and $30^{\circ} \mathrm{C}$, and the average moisture of biosolids fluctuated between 60 and $90 \%$. The estimated persistence time of viable Ascaris spp. ova after land application was estimated at close to 7 wk, indicating that ova may not be viable for as long as it has been shown to be in studies of more temperate areas. The relationship of temperature with persistence of viable Ascaris spp. ova in a tropical soil was stronger than moisture content, suggesting that temperature substantially contributed to their nonviability over the course of the experiment.
\end{abstract}

\section{Core Ideas}

- Climate conditions, mainly temperature, influence the viability of Ascaris spp. ova.

- Viable Ascaris spp. ova were not found after 7 wk of study in tropical soil.

- Agricultural use may be the best practice for disposal of biosolids.
A

MONG THE ALTERNATIVES for disposal of biosolids, application to agricultural soils is one of the best practices for several reasons: biosolids give the soil higher erosion resistance, reduce the need for commercial fertilizers, and provide a recycling option for macro- and micronutrients (Sreesai et al., 2013). Xue et al. (2015) showed that nutritional deficiencies in forests, mainly nitrogen $(\mathrm{N})$ and phosphorus $(\mathrm{P})$, can be ameliorated with the application of biosolids to forestland.

In North America, Europe, and Asia, studies involving the use of municipal biosolids on agricultural and forest soils have been conducted over more than $30 \mathrm{yr}$ and have demonstrated that application can improve soil physical properties and fertility (Van Der Hoek et al., 2002; Wang, 1997). More than half of the biosolids produced in the United States and western Europe are currently being used beneficially by way of land application (Lewis and Gattie, 2002; Lowman et al., 2013).

In these countries, studies about the persistence of viable Ascaris spp. ova on lands that have been fertilized with biosolids showed that the viability can vary from 15 mo to $15 \mathrm{yr}$ in some soils under specific conditions (Carrington, 2001; Edmonds, 2000; Kowal, 1986).

In developing countries such as Brazil, the agricultural use of municipal biosolids is viewed with caution because of the poor sanitation infrastructure and the high population parasitism index. Consequently, the main obstacles to the land application of municipal biosolids have been the high density of pathogenic organisms, such as bacteria, protozoa, viruses, yeasts, fungi, and helminths, and the lack of information about their behavior in tropical soils (Thomaz-Soccol et al., 2010).

The lack of comparable studies and the wide range of observed persistence noted in those studies points to a need

M.F. de Faria, I.A. Guerrini, L.M.L. Goulart, and T.T. de S. Silva, Dep. de Solos e Recursos Ambientais, Univ. Estadual Paulista Júlio de Mesquita Filho, Faculdade de Ciências Agronômicas, Caixa Postal 237, Botucatu, SP, 18603-970 Brazil; F.C. Oliveira, Biossolo Agricultura \& Ambiente Ltda. Rua Campos Salles, 1152, Piracicaba, SP, 13416-310 Brazil; M.I.Z. Sato and E.M. Hachich, Dep. de Análises Ambientais, Companhia Ambiental do Estado de São Paulo, Av. Prof. Frederico Hermann Júnior, 345, São Paulo, SP, 05459-900 Brazil; J.R. de S. Passos, Dep. de Bioestatística, Univ. Estadual Paulista Júlio de Mesquita Filho, Instituto de Biociências, R. Prof. Dr. Antônio Celso Wagner Zanin S/N, Botucatu, SP, 18618-689 Brazil; J.L. Gava, BSC Bahia Specialty Cellulose, Copener Florestal, Av. Dr. Jose Gomes de Camargo, 300, Alagoinhas, Bahia, 18213-640 Brazil; J.C. Furches, J. James and R.B. Harrison, School of Environmental and Forest Sciences, College of the Environment, Univ. of Washington, Box 352100, Seattle, WA 98195 USA. Assigned to Associate Editor Eddie Cytryn.

Abbreviations: $\mathrm{Cl}$, confidence interval; $\mathrm{TS}$, total solids. 
for research in tropical soils utilizing available biosolids. These studies are performed in the hope that the risks involved in the land application of biosolids on tropical soils may be determined. Thus, the objective of this study was to estimate the persistence time of viable Ascaris spp. ova after a 52-wk period in a Eucalyptus urograndis plantation in a soil fertilized with municipal biosolids.

Although the specific field conditions (i.e., temperature and moisture) might vary with specific weather conditions over the time period studied, using a forest type that represents millions of hectares of currently available, intensively managed forest plantations is the best option for understanding potential risks from Ascaris spp. ova persistence. The research hypothesis of this study was that the persistence time of viable Ascaris spp. ova would be smaller than the times shown in the literature because climate conditions could influence this group of pathogens.

\section{Materials and Methods}

\section{Characterization of the Experimental Area}

The experiment was conducted in the city of Avaré, in São Paulo State, Brazil, in a plantation of Eucalyptus grandis $\times$ Eucalyptus urophylla hybrid clones (E. urograndis) of the Suzano Papel e Celulose Company. The plantation has Quartzipsamment soil with a sandy texture and high acidity ( $\mathrm{pH}$ 4.9). Seedlings were planted at the beginning of the experiment and had reached more than $4.0 \mathrm{~m}$ in height after $52 \mathrm{wk}$.

According to the classification of Köppen and Geiger (1928), the climate of this region is humid temperate with hot summers with significant annual rainfall $(1282 \mathrm{~mm})$ and an average annual temperature of $19.8^{\circ} \mathrm{C}$ (INMET, 2015). The experiment was laid out using a randomized block design with four replications and a plot size of $10 \times 9 \mathrm{~m}$ (Fig. 1).

\section{Land Application of Biosolids}

One of the primary problems with recovering applied material from application experiments is the difficulty of differentiating soil from biosolids. To allow for high recovery of biosolids while ensuring good interaction with the environment that it was amended to, biosolid samples were placed into bags $(0.2 \times$ $1.0 \mathrm{~m}$ ) made from fabric tulle; this material allows the biosolid's surface and pores to interact with the soil. The biosolid mass packaged into each bag $(12 \mathrm{~kg})$ was consistent with the amount of biosolids distributed per linear meter, simulating the application range (Fig. 1). Biosolids were applied to the soil during the summer (in March).

The 3- $\times 2$-m spacing resulted in 1667 trees per hectare. A $\mathrm{N}$ amendment recommendation of $60 \mathrm{~kg} \mathrm{ha}^{-1}$ for the eucalyptus culture (Gonçalves et al., 1997) was used to calculate the biosolids application rate using an estimate of $30 \%$ of the total $\mathrm{N}$ present in the biosolids mineralized in the first year (Boeira and Maximiliano, 2006). This resulted in 200 $\mathrm{kg}$ total $\mathrm{N} \mathrm{ha}^{-1}$ in the biosolids to meet the $\mathrm{N}$ requirement recommendation (Gonçalves et al., 1997). The biosolid N content was $2.5 \%$, so the application required $8 \mathrm{tha}^{-1}$ of dry biosolids, or $40 \mathrm{t} \mathrm{ha}^{-1}$ of the biosolids at the $80 \%$ moisture content of the material.

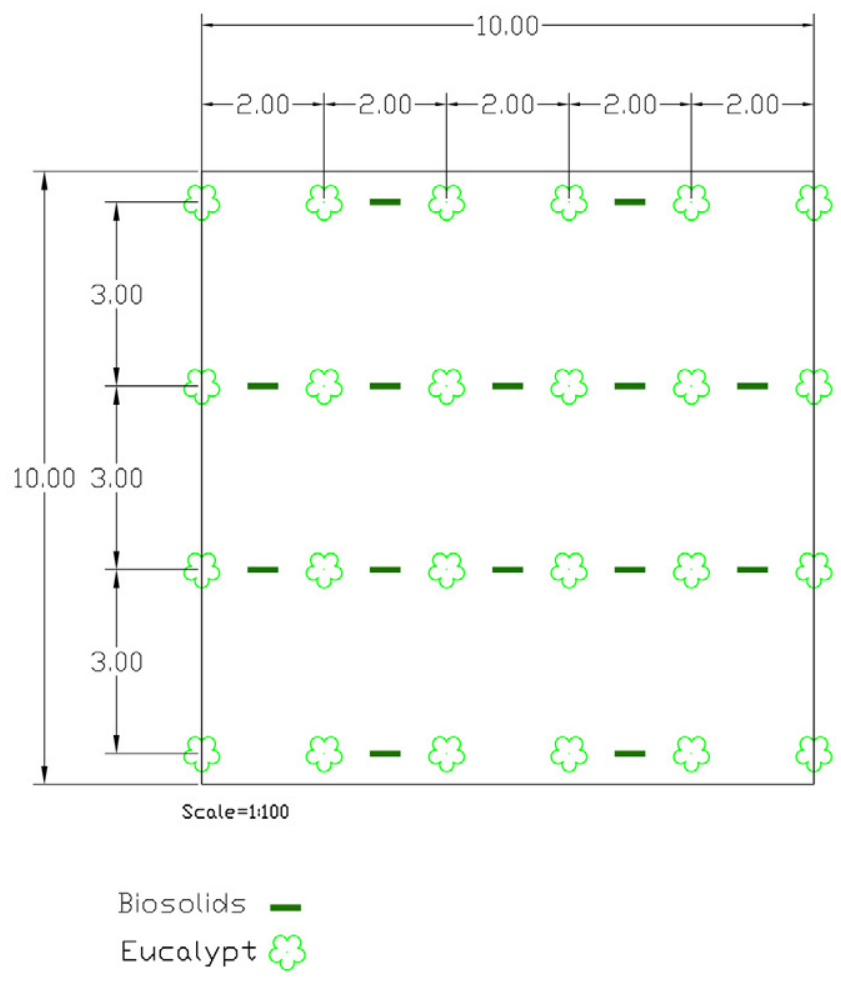

Fig. 1. Experimental plot with the bags containing biosolids and their disposition on the planting lines.

\section{Biosolids Characterization}

The biosolids used in this experiment were produced by the city of Taubaté, São Paulo State. Taubaté produces a conventional aerobically digested, activated biosolid but uses digestion tanks aerated with pure oxygen. A portion of the biosolids is inserted back into the treatment system to prime incubation, and the excess is removed and used within a few hours. The treatment capacity of the wastewater treatment plant in Taubaté is $1540 \mathrm{~L} \mathrm{~s}^{-1}$. The fast treatment system results in lower stability compared with some other systems.

The microbiological assays for biosolids characterization included thermotolerant coliforms, Salmonella spp., viable Ascaris spp. ova, and enterovirus (Table 1). Salmonella spp. and thermotolerant coliforms were quantified by Most Probable Number Technique according method 1682 from the USEPA (2006) and the Standard Methods for examination of water and wastewater from APHA (2005), respectively. Enteric viruses were concentrated by organic flocculation and quantified using plaque assay in human rhabdomyosarcoma cells (USEPA, 2003a,

Table 1. Characterization of biosolids according the concentration of pathogens per gram of total solids (TS) analyzed.

\begin{tabular}{lcccc}
\hline & $\begin{array}{c}\text { Ascaris spp., } \\
\text { ova }\end{array}$ & $\begin{array}{c}\text { Salmonella } \\
\text { spp., MPN } \dagger\end{array}$ & $\begin{array}{c}\text { Thermotolerant } \\
\text { coliforms, MPN }\end{array}$ & $\begin{array}{c}\text { Enteroviruses, } \\
\text { PFU\# }\end{array}$ \\
\hline & & & TS $^{-1}$ & \\
R1 & 4.3 & 2.83 & $2.60 \times 10^{6}$ & 10.89 \\
R2 & 3.8 & 1.51 & $1.60 \times 10^{6}$ & 9.14 \\
R3 & 4.8 & 6.82 & $8.50 \times 10^{5}$ & 9.69 \\
R4 & 6.1 & 9.37 & $2.60 \times 10^{6}$ & 0.54 \\
SD & 0.99 & 3.62 & $8.51 \times 10^{5}$ & 4.74 \\
\hline
\end{tabular}

† Most probable number.

‡ Plaque-forming unit. 
2007). Detection and enumeration of viable Ascaris ova in biosolids and soil was performed according to a USEPA technique (USEPA, 2003b). Biosolids were classified as Class B for this technique. For analytical results, $<0.1$ ova g total solids $(\mathrm{TS})^{-1}$ of soil was used as a parameter for comparison with analyses performed in biosolids.

\section{Climate Data}

Rainfall was monitored daily by a Decagon $\mathrm{ECH}_{2} \mathrm{O}$ rain gauge, model ECRN-50, connected to a Decagon Em5b data logger. Decagon 5TM Moisture \& Temperature sensors installed on the soil surface at 0.10 and $0.20 \mathrm{~m}$ deep, monitored the soil moisture and temperature hourly. The same sensors installed on the surface of the biosolid bags monitored the biosolid temperature.

\section{Sample Collection}

The collection frequency of biosolids samples was $0,1,2$, $4,6,8,10,12,16,20,28,36,44$, and 52 wk after land application. Biosolids samples were placed in sterile plastic bags and stored in a refrigerated box before being routed to Companhia Ambiental do Estado de São Paulo's Laboratory of Microbiology and Parasitology at a maximum interval of $4 \mathrm{~h}$, where the quantification of viable Ascaris spp. ova per gram of total solid sample was performed (USEPA, 2003b). At the time of the analysis in the laboratory, an electronic digital moisture balance determined the moisture of sewage biosolid samples.

\section{Data Analysis}

After obtaining the analytical results, a nonlinear regression model was fit to the data using a nonlinear equation for exponential growth curves with an asymptotic density of 0 (Seber and Wild, 2003), expressed in Eq. [1]:

$y_{i}=$ density $=\alpha e^{-\beta \text { Time }}+u_{i}$

where Time is the elapsed time (in weeks) from the experimental initiation, $y$ is the observed density of Ascaris spp. at each time point, $\alpha$ is the initial density at time $0, \beta$ is the constant decay, and $u_{i}$ is a normal random component. Modeling was performed using SAS 9.0 (PROC NLIN).

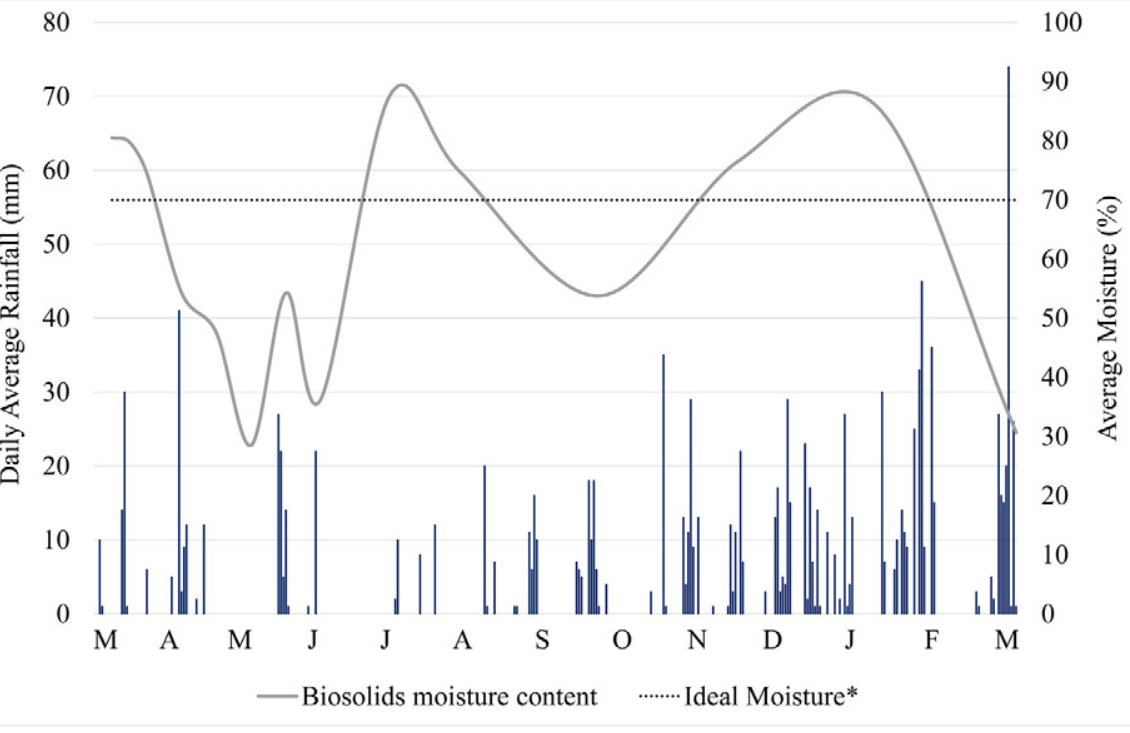

After fitting the model, the Bootstrap analysis was performed using a 95\% confidence interval (Efron and Tibsharani, 1993), and the average time was obtained by Eq. [2], for which the value of $y$ was equal to a negligible density of viable Ascaris spp. ova in the soil $\left(y=0.1\right.$ ova $\left.\mathrm{g} \mathrm{TS}^{-1}\right)$

$\hat{t}_{\min }=\frac{1}{\beta} \ln \left(\frac{\hat{\alpha}}{y}\right)$

The response of Ascaris ova persistence in soil to changes in temperature and moisture content over time was analyzed using dynamic lag linear regression (dynlm package) in $\mathrm{R}$ ( $\mathrm{R}$ Core Team, 2016; Zeileis, 2016). In addition to moisture content, the moisture deficit ( $70 \%$ moisture content) and the cumulative number of days below $70 \%$ moisture were analyzed as potential predictor variables (Thomaz-Soccol et al., 2010). For statistical analysis, the average temperature in the preceding time period (week to month) was calculated for the continuous temperature measurements at each soil depth. To determine if the response of Ascaris ova density in soil was time lagged from the moisture and temperature conditions, lagged and nonlagged variables were evaluated.

\section{Results and Discussion}

The presence of pathogens in municipal sewage is dependent on the endemic level of illness in the community and the effectiveness of wastewater treatment to remove these microorganisms. Thus, municipal biosolids may harbor a significant load of pathogens whose persistence in the soil is directly affected by environmental conditions.

Considering the climatic variables, the last 5 mo of the study had more frequent rainfall. Most of the monitoring period had weak or moderate rainfall and dry seasons. Moisture and temperature increase and decrease according to the rainfall (Fig. 2).

From a microbiological perspective, Thomaz-Soccol et al. (2010) state that, by having sensitivity to desiccation, many microorganisms present in biosolids do not survive for long periods in low moisture environments. The authors also say that the ideal moisture for survival and reproduction of these organisms is above $70 \%$.

Fig. 2. Daily average rainfall $(\mathrm{mm})$ in the experimental area and average moisture in biosolids during the $52 \mathrm{wk}$ after the beginning of the experiment. * Ideal moisture according to Thomaz-Soccol et al. (2010). 
At the beginning of the experiment, the biosolids' moisture decreased from 80 to $30 \%$, probably because of the dry season. After 16 wk, the moisture content was generally ideal for the survival of microorganisms in the biosolids.

The average temperatures of soil and biosolids had a higher irregularity at the beginning of the experiment. With increasing precipitation, the temperature became more regular, with values fluctuating between 15 and $30^{\circ} \mathrm{C}$ (Fig. 3).

The development of pathogens in biosolids can be limited by many environmental factors, among which temperature is considered to be one of the most limiting because it influences microbiological reproduction and desiccation of microorganisms (Thomaz-Soccol et al., 2010).

By adjusting a nonlinear regression model after performing the analysis to determine the persistence of Ascaris spp. ova in the biosolids along the 52 -wk study, it was possible to determine a persistence time close to $7 \mathrm{wk}$ (95\% confidence interval [CI], 5.3-11.5) and the estimated parameters $\alpha$ as 4.815 (95\% CI, $4.0946-5.5361)$ and $\beta$ as 0.583 (95\% CI, 0.394-0.773) $(p<$ $0.0001)$.

Thus, it can be inferred that after land application, under the temperature and moisture conditions during the experiment, the level of viable Ascaris spp. ova present in the biosolids took less than $7 \mathrm{wk}$ to reach the value found in the soil $\left(<0.1\right.$ ova $\left.\mathrm{g} \mathrm{TS}^{-1}\right)$ before biosolids application (Fig. 4).

The persistence of Ascaris spp. ova in soil over time was significantly related to the average temperature of the biosolids in the preceding week (adj. $R^{2}=0.63 ; F=17.8$ on 1 and $9 \mathrm{df} ; p$ $<0.005$ ) as well as the cumulative number of days below $70 \%$ moisture content (adj. $R^{2}=0.31 ; F=6.3$ on 1 and $11 \mathrm{df} ; p<$ 0.05 ) (Fig. 5). The relationship of temperature with ova survival was stronger than moisture content; temperature substantially contributed to mortality over the course of the experiment.

Studies about the viability of helminth ova, such as Ascaris, in tropical climates are scarce for many reasons. The main reason is the difficulty in finding laboratories able to perform the analysis of biosolids to determine the number of viable ova per gram of total solids according to the method proposed by USEPA (2003b) and adopted by Brazilian legislation (CONAMA, 2006).

Thomaz-Soccol et al. (1999) and Souza et al. (2008) conducted studies in different regions of Brazil incorporating the biosolids into the soil and found viable helminth ova $180 \mathrm{~d}$ and 3 wk after incorporation, respectively. The climate differences in the two regions studied clearly affected the results because the first study was located in a region that was colder and less hostile to the helminth ova.
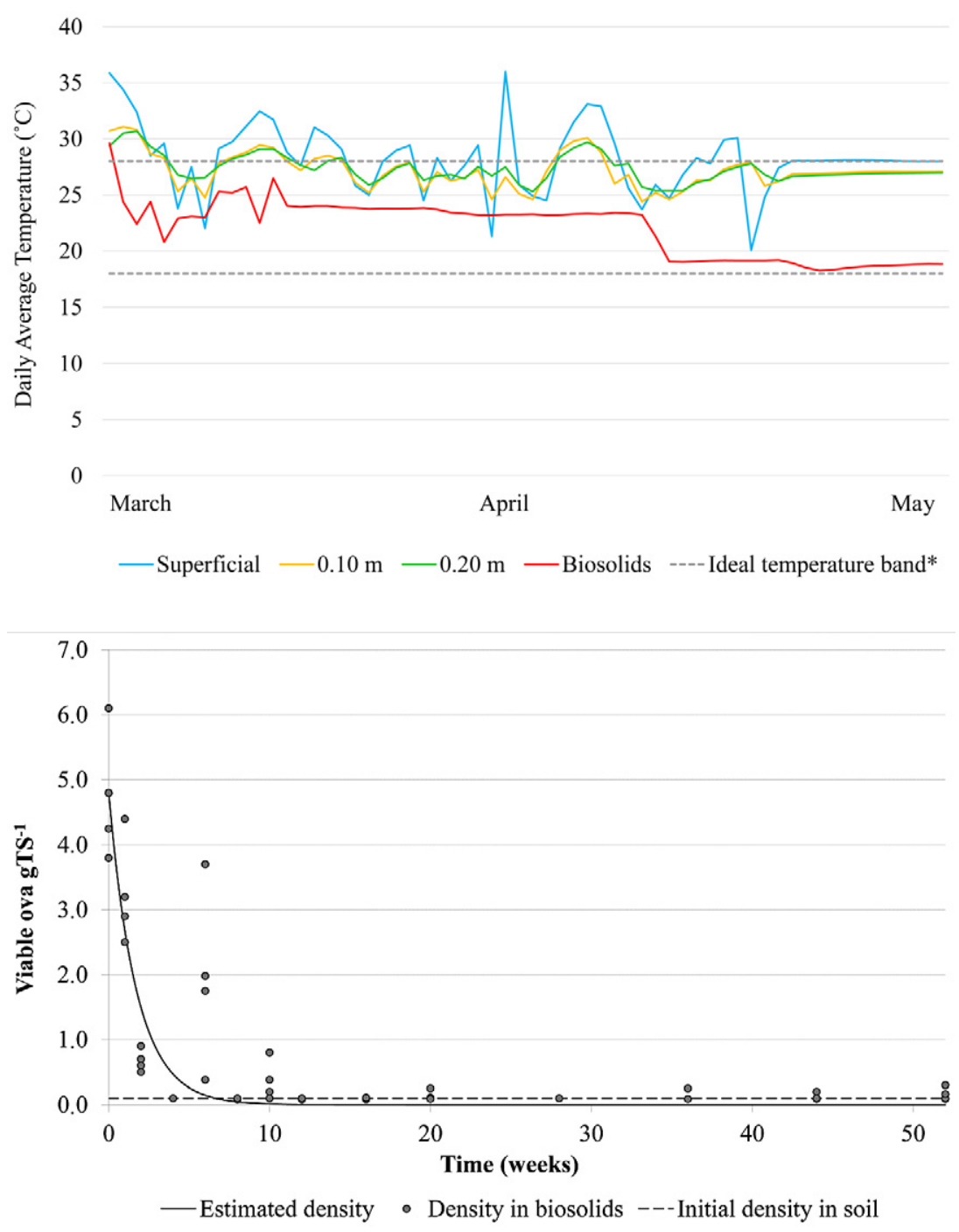

Fig. 3. Daily average temperature of soil (surface, $0.10 \mathrm{~m}$, and $0.20 \mathrm{~m}$ ) and of biosolids during the $9 \mathrm{wk}$ after land application. *Ideal temperature band for development of pathogens in biosolids according to Thomaz-Soccol et al. (2010).
Fig. 4. Density of Ascaris spp. (viable ova per gram total solids) during $\mathbf{5 2} \mathbf{w k}$ of analysis subsequent to biosolids application. 


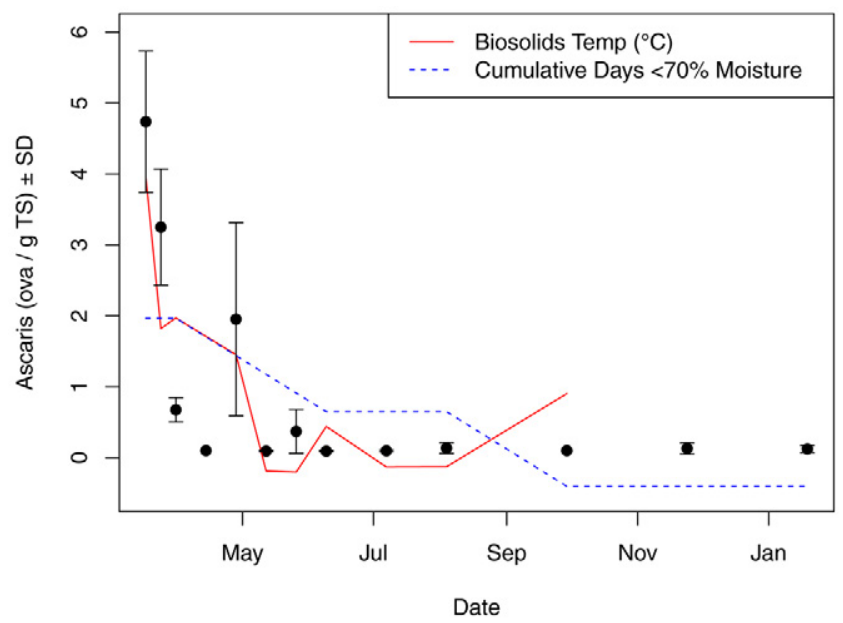

Fig. 5. The relationship between environmental variables and Ascaris ova density over time. Black circles represent average ova density across four replicates, with error bars displaying \pm 1 SD. The solid red line shows the density predicted by the average biosolids temperature in preceding week (adj. $R^{2}=0.63 ; F=17.8$ on 1 and $9 \mathrm{df} ; p<$ 0.005 ). The dashed blue line shows the ova density predicted by the cumulative days below $70 \%$ moisture content $\left(\operatorname{adj} . R^{2}=0.31 ; F=6.3\right.$ on 1 and $11 \mathrm{df} ; p<0.05)$.

Contrary to these previous studies, which examined biosolids incorporated into soil, this study opted for conditioning the biosolids into bags made of tulle that were placed on the soil surface. Consequently, the samples have been analyzed without the interference of dilution on the soil, allowing them to obtain a higher concentration of Ascaris ova without impairing the interaction with soil and environmental factors.

Studies conducted in other countries obtained different results. Munger (1983) (cited by Edmonds, 2000) said that in extreme cases it was possible to find viable Ascaris ova after 15 $\mathrm{yr}$ in certain soils and under specific conditions in cold regions. Kowal (1986) stated that, under favorable conditions of moisture, temperature, and solar radiation, helminth ova can last from 6 mo to several years in the United States. Weischer and Brown (2001) stated that Ascaris ova can take 5 yr to become unviable, according to studies conducted in Bulgaria. Carrington (2001) mentions the period of 15 mo for the nonviability of Ascaris ova in vegetative areas with temperature below $10^{\circ} \mathrm{C}$. In a study conducted in Ohio, Louisiana, and Texas, Little et al. (1991) showed that the viability of ova lasts about 3 yr under the analyzed conditions. Mizgajska (1994) states that, regardless of the type of soil, the eggs remain in the first $0.10 \mathrm{~m}$ of soil for a maximum of 17 mo.

Smith et al. (1999) affirm that Ascaris ova remain viable in soil for $7 \mathrm{yr}$ in temperate regions. The authors also say that the temperature is the environmental factor that most affects the viability of the ova, which can remain viable for up to $43 \mathrm{yr}$ when incubated at $-23^{\circ} \mathrm{C}$ and can continue developing after this period if the temperature increases. In the Arctic tundra, it is possible that the persistence of Ascaris ova lasts more than $100 \mathrm{yr}$. Still, when exposed to temperatures above $37^{\circ} \mathrm{C}$, even for short periods, the embryos begin to die, causing deactivation of the ova.

The large range of persistence times presented by different studies reinforces the assertion that external conditions influence this group of pathogens. Therefore, in the context of information from Brazil and abroad, the results obtained in this study reveal the importance and the interference of climatic conditions, mainly temperature, on the viability of Ascaris ova. Still, considering what little information is available in the literature about the resilience of this type of pathogen in tropical countries, it remains very important that larger studies be conducted in different regions and with a variety of biosolids types to clarify the doubts and questions regarding the safety of the agricultural use of biosolids in terms of public health.

\section{Conclusions}

The estimated average time for the persistence of viable Ascaris spp. ova in the biosolids applied on soil is close to $7 \mathrm{wk}$ under humid temperate climate with hot summers. Climate, especially temperature, proved to be a determining factor in the persistence of viable Ascaris spp. ova found in biosolids applied on agricultural land.

For the region where this study was conducted, the low persistence time of the viable Ascaris spp. ova in the biosolids applied in soil indicates that agricultural use is the best practice for disposal of this residue.

\section{Acknowledgments}

This work was supported by the Fundação de Amparo à Pesquisa do Estado de São Paulo, the Companhia Ambiental do Estado de São Paulo, Biossolo Agricultura \& Ambiente Ltda., Suzano Papel e Celulose S/A, Faculdade de Ciências Agronômicas-FCA/UNESP, and the USDA.

\section{References}

APHA. 2005. Standard methods for the examination of water and wastewater. 21st ed. APHA, AWWA, WPCF, Washington, DC.

Boeira, R.C., and V.C.B. Maximiliano. 2006. Dinâmica da mineralização de nitrogênio de Lodos de Esgoto. In: W. Bettiol and O. Camargo, editors, Lodo de esgoto: Impactos ambientais na agricultura. Embrapa Meio Ambiente, Sao Paolo, Brazil. p. 125-136.

CONAMA. 2006. Resolução n ${ }^{\circ} 375$, de 29 de agosto de 2006. Define critérios e procedimentos, para o uso agrícola de lodos de esgoto gerados em estações de tratamento de esgoto sanitário e seus produtos derivados, e dá outras providências. n. 167. Diário Oficial da União, Brasília, Brazil. p. 141-146.

Instituto Nacional de Metereologia (INMET). 2015. Normais climatológicas do Brasil 1961-1990. Ministério da Agricultura, Pecuária e Abastecimento, Brasília, DF, Brazil. http://www.inmet.gov.br (accessed 12 May 2015).

Carrington, E.G. 2001. Evaluation of sludge treatments for pathogen reduction: Final report. European Commission Directorate-General Environment, Luxembourg. http://ec.europa.eu/environment/archives/waste/sludge/ pdf/sludge_eval.pdf (accessed 5 Aug. 2013).

Edmonds, R.L. 2000. Microbial aspects of residuals use in forest ecosystems. In: C.L. Henry, editor, The forest alternative: Principles and practice of residuals use. College of Forest Resources, University of Washington, Seattle. p. 39-44.

Efron, B., and R. Tibsharani. 1993. An introduction to the Bootstrap. Chapman and Hall, New York. doi:10.1007/978-1-4899-4541-9

Gonçalves, J.L.M., B. van Raij, and J.C. Gonçalves. 1997. Florestais. In: B. van Raij, H. Cantarella, J.A. Quaggio, and A.M.C. Furlani, editors, Recomendações de adubação e calagem para o Estado de São Paulo. 2nd ed. rev. Instituto Agronômico de Campinas, Campinas, São Paulo State, Brazil. p. $247-259$.

Köppen, W., and R. Geiger. 1928. Klimate der Erde. Verlag Justus Perthes, Gotha. Wall map $150 \mathrm{~cm} \times 200 \mathrm{~cm}$.

Kowal, N.E. 1986. Health considerations in applying minimum treated wastewater to land. In: K.W. Brown, editor, Utilization, treatment, and disposal of waste on land. SSSA, Madison, WI. p. 27-51.

Lewis, D.L., and D.K. Gattie. 2002. Pathogen risks from applying sewage sludge to land: Despite complaints of related illnesses, little is known about the dangers of spreading biosolids on land. Environ. Sci. Technol. 36:287-293.

Little, D.A., R.B. Reneau, and D.C. Martens. 1991. Lime-stabilized and chemically-fixed sewage sludges as lime amendments. Bioresour. Technol. 37:93102. doi:10.1016/0960-8524(91)90116-2 
Lowman, A., M.A. McDonald, S. Wing, and N. Muhammad. 2013. Land application of treated sewage sludge: Community health and environmental justice. Environ. Health Perspect. 121:537-542. doi:10.1289/ehp.1205470

Mizgajska, H. 1994. The distribution and survival of eggs of Ascaris suum in six different natural soil profiles. Acta Parasitologica 38:170-174.

Munger, S. 1983. Health effects of municipal wastewater sludge: A risk assessment. Appendix B to the Sludge Management Plan. METRO Publ. 334, Municipality of Metropolitan Seattle, Seattle, WA.

R Core Team. 2016. R: A language and environment for statistical computing. R Foundation for Statistical Computing, Vienna, Austria. https://www.R project.org/ (accessed 27 Feb. 2017).

Seber, G.A.F., and C.J. Wild. 2003. Nonlinear regression. John Wiley \& Sons, New York.

Smith, H.V., T.M. Grimason, and C. Holland. 1999. Ascaris lumbricoides. In: Waterborne pathogens. American Water Works Association, Denver, CO. p. $171-180$.

Souza, C.A., J. Lemainski, J.E. da Silva, and H.A. Mazzotti. 2008. Sobrevivência de ovos de helmintos na reciclagem agrícola do lodo de esgoto no Distrito Federal. In: Simpósio Internacional de Savana Tropical, 2. Anais. Embrapa Cerrados, Planaltina, DF, Brazil.

Sreesai, S., P. Peapueng, T. Tippayamongkonkun, and S. Sthiannopkao. 2013. Assessment of a potential agricultural application of Bangkok-digested sewage sludge and finished compost products. Waste Manage. Res. 31:925-936.

Thomaz-Soccol, V., R.C. Paulino, J.T. Pereira, E.A. de Castro, A.O. Costa, L. Hennig, and C. Andreoli. 2010. Organismos patogênicos presentes em lodo de esgoto a ser aplicado no solo e a Resolução n ${ }^{\circ} 375$ do CONAMA. In: A.R. Coscione, T.A.R. Nogueira, and A.M.M. Pires, editors, Uso agrícola do lodo de esgoto: Avaliação após a Resolução n 375 do CONAMA. Fundação de Estudos e Pesquisas Agrícolas e Florestais, Botucatu, Brazil, p. 83-111.
Thomaz-Soccol, V., R.C. Paulino, and E.A. Castro. 1999. Aspectos sanitários: Agentes patogênicos: Helmintos e protozoários. In: I.K. Iskandar and C.V. Andreoli, editors, Reciclagem de biossólidos: Transformando problemas em soluções. Sanepar, Curitiba, Paraná, Brazil. p. 156-179.

USEPA. 2003a. Method for the recovery and assay of total culturable viruses from sludge. In: Environmental regulations and technology: Control of pathogens and vector attraction in sewage sludge. USEPA, Washington, DC.

USEPA. 2003b. Test method for detecting, enumerating and determining the viability of Ascaris ova in sludge. In: Environmental regulations and technology: Control of pathogens and vector attraction in sewage sludge. USEPA, Washington, DC. p. 166-172.

USEPA. 2006. Method 1682: Salmonella in sewage sludge (biosolids) by modified semisolid Rappaport-Vassiliadis (MSRV) Medium. EPA 821-R-01614. USEPA, Washington, DC.

USEPA. 2007. Preliminary comparative study of methods to extract virus from raw and processed sewage sludge. EPA 600/R-07/118. USEPA, Washington, DC.

Van Der Hoek, W., M.U. Hassan, J.H.J. Ensink, F. Feenstra, L. Raschid-Sally, S. Munir, et al. 2002. Urban wastewater: A valuable resource for agriculture: A case study from Horoonabad, Pakistan. International Water Management Institute, Colombo, Sri Lanka.

Wang, M.J. 1997. Land application of sewage sludge in China. Sci. Total Environ. 32:149-160.

Weischer, B., and D.J.F. Brown. 2001. Conhecendo os nematóides: Nematologia geral. Pensoft, Sofia-Bulgária.

Xue, J., M.O. Kimberley, C. Ross, G. Gielen, L.A. Tremblay, O. Champeau, et al. 2015. Ecological impacts of long-term application of biosolids to a radiata pine plantation. Sci. Total Environ. 530-531:233-240. doi:10.1016/j. scitotenv.2015.05.096

Zeileis, A. 2016. Dynlm: Dynamic linear regression. R package version 0.3-5. http://CRAN.R-project.org/package=dynlm (accessed 27 Feb. 2017). 